症例

術前診断しえた，成人腸回転異常による中腸軸捻転症の 1 例

\begin{tabular}{|c|c|c|c|c|c|c|c|c|}
\hline & & & & 渏病 & 浣外 & & & \\
\hline 本 & 弘 & 一 & 島 & 田 & 和 & 典 & 木 & 下 \\
\hline 口 & 時 & 雄 & 中 & 鳥 & 信 & - & 後 & 藤 \\
\hline
\end{tabular}

症例は22歳男性，心墖部痛，嘔吐を主訴に当院受診した。上部消化管内視鏡検査にて 胃から十二指腸下行脚までの拡張を認めた。 上部消化管造影検查にて，十二指腸空腸移 行部の位置異常, 上部空腸に狭窄部を認めた。注腸検查では結腸全体の左側偏位と上行 結腸に捻転部と思われるループを認めた.腹部 CT では上部空腸が上腸間膜動脈(SMA) をとりまく所見が得られ, 造影 CT にて上腸間膜静脈 (SMV) はSMA の左側に位置し ており, 腸回転異常に伴う中腸軸捻転症と診断した。手術所見では術前診断通りで，中 腸は時計方向に $360^{\circ}$ 捻転していた. Ladd 靶帯および虫垂を切除, 捻転を整復し, 空腸お よび回腸は SMA の右側に，結腸は左側に位置する nonrotation の状態として手術を終 了した．本疾患の成人発症例は稀であるが，その可能性を念頭に置いて画像検查を施行 すれば術前診断可能と考えられた。

索引用語：腸回転異常, 中腸軸捻転症, 成人

緒言

腸回転異常は, 胎性期の中腸の回転抢よび固定の異 常に起因する先天異常であり，これのみでは症状を呈 することは少ない．しかし中腸の軸捻転を来すと手術 を要する場合が多い.ほとんどは新生児期に発症し， 成人してから発症するのは稀である12). 今回われわれ は成人における腸回転異常に伴う中腸軸捻転症と術前 診断しえた症例を経験したので報告する。

\section{症 例}

患者：22歳, 男性.

主訴：腹痛, 嘔吐.

家族歴：特記すべきことなし。

既往歴：幼少時, 過食により時折腹痛を訴えていた が，それ以外に特記すべきことなし。

現病歴：平成11年 2 月より腹痛・嘔吐を認め保存的 に加療していたが，症状が増恶したため平成11年 2 月 23日精查加療目的に当院入院した。

入院時現症：腹部は平坦，軟であった。

血液生化学検査所見：WBC $10,100 / \mathrm{mm}^{3}$, CRP 5.0

2000 年 4 月 10 日受付 2000 年 6 月 28 日採用

〈所属施設住所〉

₹652-0042 神戸市兵庫区東山町 3-3-1 $\mathrm{mg} / \mathrm{dl}$ と上昇していたが, 生化学検査, CEA および CA19-9は正常値であった.

上部消化管造影：十二指腸空腸移行部の位置異常, 空腸に狭窄部と渦巻き様走行, および上部空腸の右側 偏位を認めた（図 1 ).

注腸検査：注腸検査では結腸の左側偏位と，捻転部 と思われるループを認めた（図2）。

腹部 CT 検查：上部空腸が SMA をとりまく所見が 得られ(図 $3 a$ ), 造影 CT にて SMV はSMA の左側 に位置していた（図 3 b).

以上より腸回転異常に伴う中腸軸捻転症と術前診断 し，4月 2 日手術施行した。

手術所見：上腹部正中切開にて開腹. 十二指腸前面 を Ladd 勒帯が覆っており，これを切除したが，Ladd 靶帯による十二指腸の圧迫は軽度であった（図 4 a). 回盲部は正中に位置しており, 虫垂切除を施行した(図 $4 \mathrm{~b})$.上部空腸から上行結腸までの中腸は時計方向に $360^{\circ}$ 捻転しており（図 $4 \mathbf{c}$ )，これを整復，小腸は腹腔 内右側，結腸は左側に位置する nonrotation の状態と して手術を終了した. 腸管の固定は施行しなかった。 術前 CT 通り SMVはSMA の左側に位置していた (図 4 d).

術後経過：腸蠕動の回復遅延が認められたが, 保存 


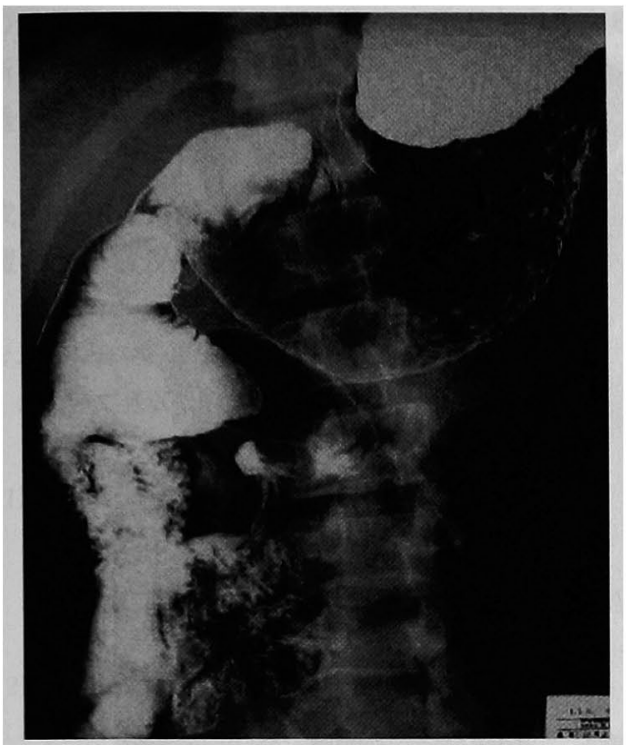

図 1 上部消化管造影検査：十二指腸空腸移行 部の位置異常, 空腸に狭窄部と渦巻様走行, お よび上部空腸の右側偏位を認めた。

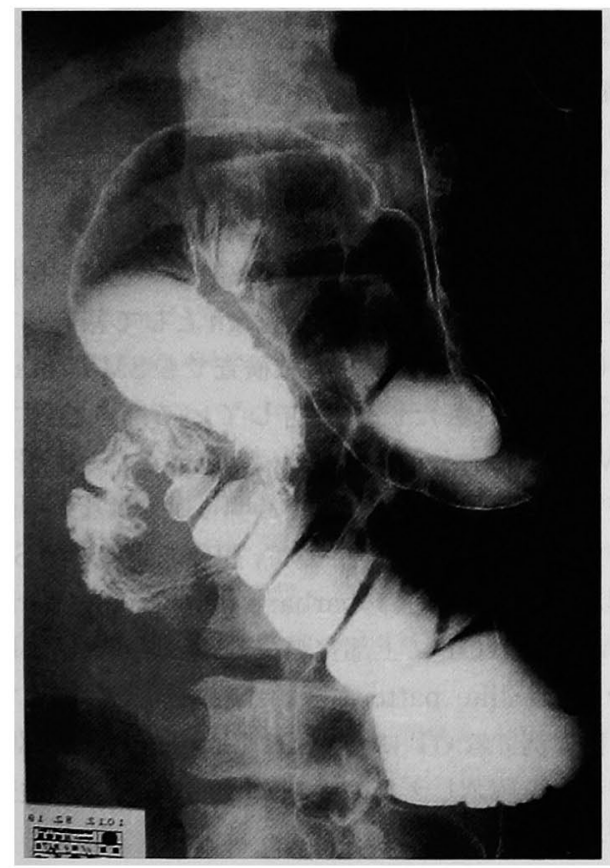

図 2 注腸検査：結腸の左側偏位と捻転部と思 われるループを認めた。

的に軽快し，術後40日目に退院した。現在，症状なく 経過良好である。

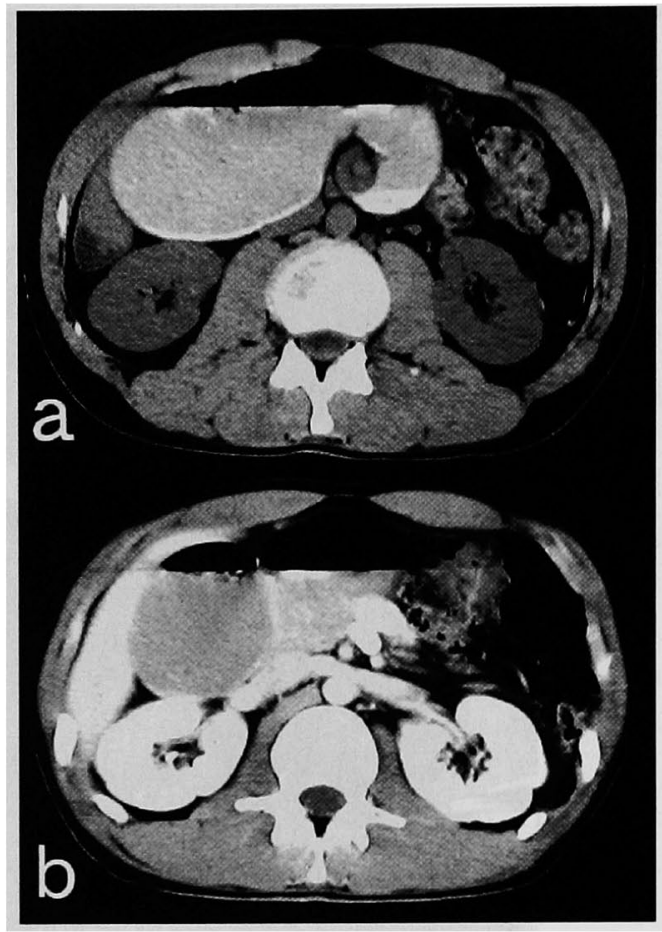

図 3 腹部 CT 検查：上部空腸が SMA をとりまく 所見が得られ (whirl-like pattern) (a), 造影 CT にて SMV は SMA の左側に位置していた（SMV rotation sign) (b).

\section{考察}

Snyder ら 2)によると中腸は胎生期に270度の回転を 行って正常の位置に固定されるといわれている。この 回転・固定が正常に行われない病態を腸回転異常とい う. 腸回転異常の分類は種々のものがあるが2)-9), 中 條 ${ }^{9}$ の分類にしたがえば，90回転症（狭義の nonrotation) と $180^{\circ}$ 回転症 (malrotation), 腸管逆回転症, 傍 十二指腸へルニアに大きく分けられる.

腸回転異常自体は無症状であるが，以下の場合問題 となる，1つは右側腹壁と上行結腸を結ぶ異常䩗帯で ある Ladd 䩘帯により十二指腸が圧迫される場合であ る.また malrotation の場合，上部空腸と上行結腸と による pedicle を心として捻転を生じやすく，中腸 軸捻転症といわれている ${ }^{10) 11)}$. 自験例は中腸軸捻転症 を伴った malrotationで中條の分類では $180^{\circ}$ 回転症 (接着型) + Ladd 䩰帯十時計方向 $360^{\circ}$ 捻転であった。 中腸軸捻転症は新生児期に腸閉塞の症状を現わして 発見されることが多く，その際は，早急に手術に踏み 切ることが肝要とされている ${ }^{10111}$. 


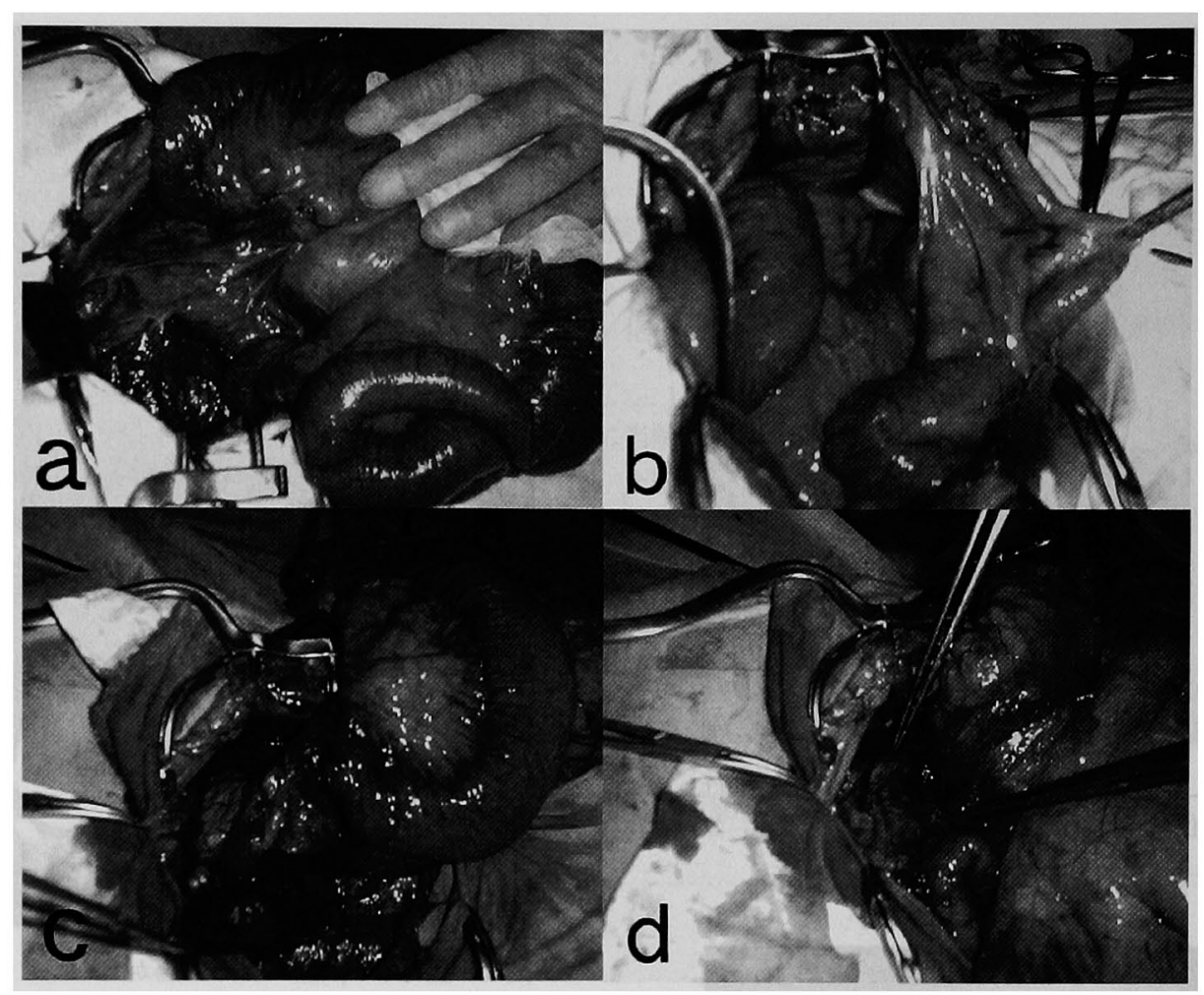

図 4 術中所見：(いずれも向かって左が頭側)：十二指腸前面を Ladd 鞋帯が覆っていた (a). 正 中に回盲部を認めた (b). 中腸は時計方向に360埝転していた (c).SMV は SMAの左側に位置 していた（d).

腸回転異常の成人報告例は比較的稀で, 本邦では 1990年から1999年の10年間で自験例を含め66例であっ た. 記載により中條の分類にあてはめられた55例の内 訳は, nonrotation が33例, malrotation が15例, 腸管 逆回転症が 3 例, 傍十二指腸ヘルニアが 4 例であった。 腸回転異常は他疾患の精查中偶然みつかることが多 く, 腸回転異常により症状を呈したのは, Ladd 靯帯に よる圧迫が 1 例, 中腸軸捻転症が自験例を含め 15 例を 数えるのみである，成人の場合，捻転したままで慢性 的な経過を示すこともある ${ }^{22}$.

小児・成人を問わず, 腸回転異常の診断は, 造影検

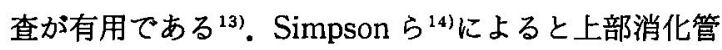
造影検查では，(1)十二指腸水平脚での狭燋，(2)十二指 腸空腸移行部の位置異常, (3)上部空腸の右側偏位が特 徵としている.特に(2)および(3)は腸回転異常に特徴的 で他疾患との鑑別上重要である。このためSimpsonら も狭窄部を通過して上部空腸まで造影すべきであると 強調している。また注腸造影検査では, 結腸全体の左 側偏位がみられる．腹部 CT 検査等では Nichols ら ${ }^{15}$
が本来 SMA の右側に位置する SMV が左側に位置し ていることを SMV rotation sign として報告してい る. Gaines ら ${ }^{16)}$ は腹部超音波検查でもSMV rotation signを確認できた例を報告している。自験例では SMV rotation sign はCTでは確認できたが，超音波 検査では十二指腸の拡張のため明らかではなかった。

一方, 捻転合併の所見として, 腹部血管造影で SMA が螺旋状の走行を示す barbar pole signをGriska

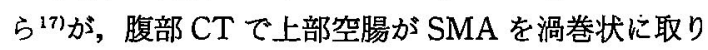
囲むwhirl-like pattern Fisher ら ${ }^{18}$ が報告してい る. 自験例では CT にて whirl-like-pattern を認め捻 転の合併を確認しえたので，侵襲的な血管造影検查は 施行しなかった.

治療は Ladd 手術である ${ }^{19)}$.すなわち Ladd 勒帯を 切除し, 上部空腸と上行結腸の距離を大きく開くこと がコツとされている．整復後, 腸管を後腹膜に固定す るか否かは議論の分かれるところである. Bill ら よると腸管の固定によって再捻転の防止となるとされ ているが, 異論も多く, 腸管と腹壁との固定は行わな 
いのが通常である．腸回転異常に虫垂炎を合併すると 診断・治療に難渋することがあり，このため予防的に 虫垂切除を併施することは妥当と考えられている21). 結語

成人の腸回転異常は稀な垁患であるが，これを念頭 に置き画像検査をすすめれば術前診断可能と思われ た.

なお, 本論文の要旨は, 第61回日本臨床外科学会総会 (東 京）において発表した。

\section{文 献}

1) Stewart DR, Colodny AL, Daggett WC: Malrotation of the bowel in infants and children: A 15 year review. Surg 79:716-720, 1976

2) Snyder WH, Chaffin L:Embryology and pathology of the intestinal tract: Presentation of 48 cases of malrotation. Ann Surg $140: 368$ $-380,1954$

3) Bill $\mathrm{AH}$ : Malrotation of the intestine. In Pediatric Surgery : 912-923, 1979

4）角田昭夫：腸回転異常症（malrotation）と輪状 膵. 小児外科・内科 $4: 171-179,1972$

5) Estrada RL, Gurn FN : Surgical correction of reversed rotation of the midgut loop. Surg Gynecol Obstet 114 : 707-718, 1962

6) Grob $M$ : Lehrbuch der Kinderchirurgie. George Thieme Verlag, Stuttgart 1:348-352, 1957

7) Soderlund $S:$ Anomalies of midgut rotation and fixation. Acta Paediatr [Suppl] $135: 225$, 1962

8) Rickham PP, Lister J : Malrotation and volvulus of the intestine. In : Neonatal Surgery : 371-380, 1978

9）中條俊夫：腸回転異常. 小児外科学, 診断と治療 社, 東京, 1979, p156-161

10）大神 浩：腸管回転異常. 出月康夫, 新外科学大
系, 30C 小児外科1II, 中山書店, 東京, $1991, \mathrm{p} 205$ $-219$

11) Stewart DR, Colodny AL, Daggett WC, et al : Malrotation of the bowel in infants and children: A 15 year review. Surg $79: 716,1976$

12）住友健三, 池田真一, 徳永滋彦他: 慢性中腸軸捻 転症を伴った腸回転異常の1例. 外科診療 4 ： 537-540, 1992

13）田中優美子：成人における腸回転異常に伴う腸軸 捻症：臨放線 36：651-656，1991

14) Simpson AJ, Leonidas JC, Krasna IH, et al: Roentgen diagnosis of midgut malrotation; value of upper gastrointestinal radiologic study. J Pediatr Surg 7:243-257, 1972

15) Nichols DM, Li DK : Superior mesenteric vein rotation. A CT sign of midgut malrotation. Am J Radiol 141 : 368-379, 1983

16) Gaines PA, Sauders AJS, Drake D, et al: Midgut Malrotation Diagnosed by Ultrasound. Clinical Radiology 38: 51-53, 1987

17) Griska LB, Popcky GL : Angiography in midgut malrotation with volvulus. Am J Roentogenol 134 : 1055-1056, 1980

18) Fisher JK : Computed tomographic diagnosis of volvulus in intestinal malrotation. Radiol 140 : 145-146, 1981

19) Ladd WE: Surgical diseases of the alimentary tract in infants. New Engl J Med : 705-708, 1936

20) Bill AH, Grauman D : Rationale and technique for stabilization of the mesentery in cases of nonrotation of the midgut. J Pediatr Surg 1: 127-136, 1966

21）鹿野泰昭, 脇山茂樹, 雷 哲明他：虫垂切除術に 難泚した成人腸回転異常症の 1 例. 外科 $54: 306$ $-308,1992$ 


\title{
AN ADULT CASE OF DIAGNOSED PREOPERATIVELY MALROTATION OF THE INTESTINE WITH MIDGUT VOLVULUS
}

\author{
Koichi KAWAMOTO, Kazunori SHIMADA, Kouji KINOSHITA, Tokio YAMAGUCHI, \\ Nobukazu NAKASHIMA and Masanobu GOTO \\ Department of Surgery, Kawasaki Hospital
}

\begin{abstract}
A 22-year-old man was admitted to the hospital because of epigastric pain and vomiting. Upper gastrointestinal endoscopy showed a dilatation from the stomach to duodenum. An upper gastrointestinal study revealed stenosis of the jejunum, abnormal position of the duodenojejunal junction, and the proximal jejunal loops to the right of the midline. Barium enema study showed that the ascending colon dislocated to the midline (left-sided colon). Abdominal CT scan revealed a whirl-like pattern, consistent with proximal jejunum encircling the superior mesenteric artery. Enhanced CT scan also showed SMV rotation sign, proximal SMV lied on the right ventral aspect of the SMA. A diagnosis of malrotation of the intestine with volvulus of the midgut was made. At laparotomy, the midgut twisted clockwise by $360^{\circ}$. Ladd's procedure and appendectomy were performed.

Although the midgut volvulus is rare in adults, preoperative diagnosis may be made if the possibility of this disease is kept in mind.
\end{abstract}

